\title{
Virtue and responsibility: Economic-ethical perspectives in the work of Etienne de Villiers
}

\begin{abstract}
Author:
Piet J. Naude ${ }^{1}$

Affiliation:

${ }^{1}$ Unit for Professional

Ethics, Nelson Mandela

Metropolitan University,

South Africa

Correspondence to:

Piet Naude

Email:

piet.naude@nmmu.ac.za

Postal address:

PO Box 77000, Port Elizabeth

6031, South Africa

Dates:

Received: 04 May 2012

Accepted: 14 Aug. 2012

Published: 06 Dec. 2012

How to cite this article: Naude, P.J., 2012, 'Virtue and responsibility: Economicethical perspectives in the work of Etienne de Villiers', Verbum et Ecclesia 33(2), Art. \#737, 6 pages. http://dx.doi. org/10.4102/ve.v33i2.737
\end{abstract}

(C) 2012. The Authors. Licensee: AOSIS OpenJournals. This work is licensed under the Creative Commons Attribution License.
This article was developed in six statements and attempted to reconstruct the basis for the socio-economic ethics of Etienne de Villiers, as well as its ecclesio-centric nature and theoretical formulation in virtue and responsibility ethics. There was reference to De Villiers's shift from an exclusive to an inclusive ethical view as a response to his interpretation of modernity and secularism. Critical questions were raised as to the actual theological character of his ethics and his re-interpretation of Weberian responsibility ethics. The article concluded with an appreciative view on the applied ethics perspectives developed by De Villiers over the last three decades.

\section{Introduction}

This article aims at outlining the economic-ethical dimension of Etienne de Villiers's oeuvre. Instead of focusing on particular aspects of his ethical thought related to the economic sphere poverty, distributive justice and globalisation - the article is developed in six directive statements that attempt to place his economic ethics within the trajectory of his whole thinking. The first four statements deal with his confessional basis in the Reformed tradition, the institutional form related to the visible church, the core theoretical aspects from which his thoughts are drawn, as well as his perennial struggle with the question of the uniqueness of a Christian morality is outlined. This exposition forms the basis for the two last statements where critical questions about the theological character of De Villiers's work, and the unique contributions he made in many areas of ethics, notably economic ethics, are expounded.

\section{First statement}

Etienne de Villiers moves from an evangelical to a social-ethical perspective as a result of his acceptance of the Reformed tradition, on the basis of which he is able to develop fruitful economic-ethical views on (for example) poverty and economic equality.

Etienne de Villiers grew up in the context of evangelical Christian pietism. This version of the Christian faith places great emphasis on personal faith and holiness and may, at times, not be able to fully address the socio-political dimensions of the gospel. It was the pietistic tendency that 'often resulted in an almost exclusive concentration on religious matters and an uncritical acceptance of unjust political policies' (De Villiers 2001a:17).

According to De Villiers, he moved toward a more social Christian vision as a result of his exposure, on a personal level, to social philosophy and student politics at Stellenbosch University in the late 1960s ${ }^{1}$ and exposure to people such as Allan Boesak, Hannes Adonis and Johannes Verkuyl whilst studying for a doctorate in the Netherlands. These experiences and discussions 'awakened in me the desire to reflect more directly on relevant political and economic issues. The shift to Christian Ethics seemed natural and inevitable' (De Villiers 2001a:18). This social consciousness then found a theological voice via his overt acceptance of the Reformed faith's perspective on God's rule over all of creation.

De Villiers provides the outline of a specific Reformed social ethics by demarcation on two sides. On the one hand, he refers to the two kingdoms vision associated with Lutheranism, which might lead to a view that aspects of reality are not to be seen as being under the rule of Christ but governed purely by common sense rationality. On the other hand, he refers to the rise of Pentecostalism, which, in most forms, propagates a strict division between 'church' and 'the world out there', leading, in a contradictory way, to exactly leaving the world beyond the reach of the Christian faith (De Villiers \& De Beer 2009:110).

1.In his own words: 'Less a result of theological classes and more the intellectual stimulation that I experienced in philosophy, and linked to my involvement in student politics, this transformation broke my intellectual naïvete' (De Villiers 2001a:17). For an illuminating interpretation of De Villiers's biography in relation to his public theology, read Bezuidenhout (2007:164-175). 
The Reformed vision, however, operates with a 'Theo-logy' (view of God) that accepts the rule of God over all of creation and history. This is ethics with an all-embracing kingdom ${ }^{2}$ vision which includes all aspects of life - including the economy. A Reformed ethical vision accepts the total corruption of the human person as source of injustice (also in economics), but, at the same time, professes both the full and cosmic reconciliation in Christ and the view that Christ transforms culture. Another distinct aspect of Reformed ethics is the notion of 'calling'; that is, the responsibility of Christians to serve the purposes of God in the transformation of the world (De Villiers 2005:521-522).

\section{Second statement}

One could call De Villiers's ethics an ecclesio-centric ethics because the institutional church - specifically the Dutch Reformed Church-forms the constant institutional basis and reference point of his thought.

De Villiers is a church theologian in the positive sense of the word. He is an ordained pastor and professor in service of the church and, through the church, he is in service of the gospel in the wider society. But the Dutch Reformed Church (DRC) is the first and foremost 'public' he wishes to address. In this regard, it is possible to distil at least five specific conditions for a credible ecclesial ethics as set out by De Villiers in various parts of his work ${ }^{3}$ :

- The recognition of social-ideological hermeneutics. It is impossible for a church such as the DRC (for example) to be self-critical of its own ethical views unless it fully acknowledges the social conditioning of these views and the ideological presuppositions in which its views are undeniable embedded. One could say that De Villiers draws on the so-called Second Enlightenment ${ }^{4}$ - the hermeneutics of suspicion emanating from Marx, Nietzsche and Freud - to instil a critical dimension in a self-satisfied church.

- The development of an encompassing spirituality. De Villiers is at pains to point out that White, Afrikaansspeaking Christians should resist the temptation to withdraw from public life after their relative loss of political power since 1994. He knows the strengths of a pious spirituality, but he also recognises the challenge for the church to foster an outward-driven spirituality that would include action in the economic sphere of life.

- The establishment of the church as an inclusive community of compassion. The DRC has a proud history of caring for the poor and the struggling. But the problem is that this was directed toward its own members and - in related sense - to far-off communities in the context of mission. An ethics of inclusive care would practice love without seeing the person.

- A radical re-orientation in the new South African situation after 1994. De Villiers spends quite a lot of energy on a

2.See De Villiers's (2008:380, especially fn. 5) defence of the concept 'kingdom of God' as being relevant even in postmodern times.

3.For various references to these ecclesiological views, read De Villiers (1995b:567568, 1999b:27-33, 2008:380-383).

4.For a discussion of the 'Second Enlightenment' in an ecclesiological context, see Jonker (2008:19-25). discussion of the impact of Enlightenment ideas on the ordinary Christians' perspectives: modernity and liberalisation operate on the basis of a division between church and state. The public recognition of 'Christian' values can therefore no longer be taken for granted and laws will not necessarily reflect the gospel view. But freedom of religion provides new opportunities and De Villiers is adamant that unless DRC members overcome their principled 'victim attitude' (slagoffermentaliteit) toward our democratic dispensation, public ethics will not be possible.

- The reunification of the DRC Family is seen by De Villiers as a very important marker of Christian credibility. If the churches in the family - divided on racial grounds cannot find one another in visible unity, their witness on matters of reconciliation and justice will not find fertile public recognition.

Based on these guidelines, De Villiers then challenges the DRC to address the issue of creating a just economic system in South Africa. He believes this church has, in its groundbreaking Church and society (Kerk en samelewing) document of 1986 (revised 1990) ${ }^{5}$, set down useful biblical principles that could assist in this regard: love of the neighbour (including the enemy!), a biblical sense of justice and of care, as well as a strong reliance on the God-given human dignity of each person, all of which provide a strong basis to address the difficult question of economic justice in a democratic South Africa.

De Villiers does not hesitate to be quite concrete. If these principles are accepted, at least four aspects should be included in a programme to establish a more just economic dispensation $^{6}$ (De Villiers 1991:27-29; see also De Villiers 1995b:565-567):

- Firstly, neutrality about economic issues is not an option, as this would imply condoning of the unjust, historically developed, status quo. There must be a clear commitment to a more just distribution of wealth and affirmative action must be taken seriously as part of restitution in the context of White peoples' unrealistically high lifestyle.

- Secondly, social spending by the state should be equalised - for this the church must express support, whilst, at the same time, serving the poor via the church without distinguishing amongst people.

- Thirdly, the DRC must set an example in the way it spends its own resources, keeping in mind that its relative wealth was built on the privileged position of White people over many years. The church must call its own members to a more sober and simple lifestyle and can only ask the state for equality of remuneration for different race groups if parity in salaries of all ministers in the DRC Family is also propagated.

5.See De Villiers (2001c:54) for a discussion of Kerk en samelewing as part of the DRC's indirect influence on public policy at the time. He is supportive of the 1990 revised version, as this document takes a more critical stance against the socio-political version, as this document takes a more critical stance against the socio-political
views of the preceding years. For a most recent discussion of the significance of Kerk en samelewing after 25 years, read Strauss (2011).
Ker

6.On actions to take in the context of growing global inequalities, read De Villiers (2001c, specifically pp. 474-476). 
- Fourthly, the DRC must convince its own members of the importance of preparing themselves for the sacrifices and lifestyle adjustments required by a more just economic dispensation for all.

\section{Third statement}

Etienne de Villiers approaches social-ethical questions, including economic justice, from two theoretical perspectives, namely a virtue ethics as set out by Stanley Hauerwas and - more significantly an ethics of responsibility derived from Max Weber and subsequent thinkers. $^{7}$

Concerning a virtue ethics, De Villiers - in line with his ecclesio-centric views - proposes that it is the task of the church to build the character of its members in line with appropriate Christian virtues, leading them, in the end, to mature moral decision-making. Virtue ethics has important implications for the economic sphere, as it can assist in the character formation of business people with values such as honesty and social responsibility, leading them to take economic decisions on the basis of their Christian morality (De Villiers 1999b:33-34, 2001a:21).

When De Villiers brings his interpretation of a responsibility ethics to bear in the economic sphere, he cites four forms of complementarity that should be kept in constant balance (De Villiers \& De Beer 2009:112-118). ${ }^{8}$ Firstly in this regard, is the complementarity of self-responsibility and co-responsibility for the poor. Christians are called as individuals to care for the poor as part of the moral dimension of their own lives. But individual action may be totally inadequate in addressing the structural dimensions of poverty. Therefore collective cooperation on the basis of co-responsibility is also required to specifically address both the social and policy dimensions of poverty. Christians should not hold back on participating even with non-religious parts of civil society and taking up their prophetic task to call others to responsible action in this regard.

Secondly, is De Villiers's view of the complementarity of empirical facts and the reality in Christ. Assisting the poor must be based on direct cooperation with poor people in order to understand their actual needs, coupled with relevant scientific data to provide a reality check for ethics. Many development aid projects from the West have failed exactly because real needs and cooperation of local communities in designing and executing such projects were absent. But Christians also - at the same time - hold onto the 'in Christ' reality and the potential for a new society drawn from the inclusive salvation in him. One is led by the concrete situation on whether to uphold an ideal morality or whether to settle for an optimal morality (De Villiers 2003:34).

7 .'In the end, an ethics of virtue and an ethics of responsibility indeed do not exclude one another. They inevitably complement one another' (De Villiers 2001a:21).

8.These four dimensions of a responsibility ethics are derived from Max Weber and form a common thread in De Villiers's work. Read De Villiers (2003:31-36, 2010b) for a more academic and mature exposition of an ethics of responsibility in dialogue with Max Weber and with Dietrich Bonhoeffer, Hans Jonas, Johannes Fischer and Wolfgang Huber. See, specifically, De Villiers (2010b:269-275), where the same Wolfgang Huber. See, specifically, De Villiers (2010b:269
points as above are made in a more elaborative fashion.
Thirdly, is the complementarity of moral and functional values. Christians are used to maintain the primacy of moral values based on their specific Christian convictions. It is desirable that in a situation of modernity Christians hold onto the validity of moral values for all spheres of society. But at the same time, they should recognise the validity of system-immanent or functional values governing the different spheres of society and linked to specific role responsibilities. Christians therefore have the difficult task of translating moral values for application in a specific area like the economy in the hope of achieving a significant degree of 'overlapping consensus' (Rawls 1993:133-172) between moral and functional values. (e.g. what does 'love of the neighbour' mean in the case of mergers or acquisitions, where job losses are at stake?)

Lastly, is the complementarity of deontology (principles) and utility (consequences). In the tradition of the DRC, Christian ethics has often been constructed as 'God-given' or 'biblical' principles that should guide action and, in this way, resemble a deontological type of ethics. An ethics of responsibility requires an equally important consideration for the consequences of actions, including the consequences following adherence to specific principles. These utility considerations should be taken into account in advance of an action so that Christians wilfully deliberate on the effect of their intended actions and take responsibility for these as well. In line with his view on the option for the poor, De Villiers (2001a:19) states that actions with the most advantages for poor people should therefore get preference.

\section{Fourth statement}

A recurring motif in De Villiers's work is the struggle to ground and defend the uniqueness of Christian morality, a view that he at first defends, but later amends to develop an applied 'ethics of compromise' in the light of his interpretation of secularism and modernisation.

What brings De Villiers to a qualified Christian ethics or an ethics of compromise? There are a number of factors that work in a cumulative fashion to gradually convince him of the necessity to make this shift, the first of which is the increasing pluralism of ethical views from within the broad Christian tradition, which itself makes the claim for a 'unique' Christian perspective very difficult if not almost impossible. This relativity is intensified in a liberal democracy where individual human rights, and not necessarily distinct Christian values, shape the ethics and laws of the country making room for a great diversity of views.

Furthermore - especially in fields of applied ethics - there is no way that a responsible ethical view can be developed without recourse to insights derived from philosophy and from the science (or whatever field of knowledge) under discussion. One cannot - according to De Villiers (2009:116117) - develop a responsible ethics without taking the distinction between specific role and more general moral responsibilities seriously, and neither of these need to be specifically 'Christian'. 
There is a definitive apologetic intent in De Villiers's call for Christians to no longer depart from theocratic assumptions, but to live in two value systems: the basically secular value system and Christian values. This stems from the perennial question in his work related to the 'uniqueness' of Christian moral convictions. ${ }^{9}$ He therefore adds:

If we, however, want these values to be accepted and applied in our democracy we will have to use language which nonChristians can understand and arguments which they can accept. (De Villiers 2001c:59) $)^{10}$

On the basis of these considerations, De Villiers makes a paradigmatic shift in his ethical orientation: the earlier exclusive Reformed view of social transformation with the rule of Christ as reference point is augmented by an inclusive transformation, which aims at the humanising of society (anthropocentric dimension) and the optimising of all life on the planet (ecological dimension) ${ }^{11}$ with the concomitant prospective responsibilities (Jonas) related to the future of the whole creation. This does not mean that De Villiers gives up on his argument for the specificity of a Christian contribution to ethics. He purports that the specific Christian preferential option for the poor is an important contribution to economic ethics. The spiritual content of socio-economic development should also be kept in mind in determining the unique contribution of the Christian faith. De Villiers (1995a) refers to the government's reconstruction and development plan as a specific example where the church can play a role. He also mentions the fact that moral motivation is an important dimension in determining the moral quality of an action (De Villiers 1995b:567) and that the specific Christian motives, such as love and hope, can spur people on to do good deeds - including actions in the economic sphere.

Despite making room for the enormous impact of secularism and modernism, De Villiers does not relinquish the possibility of a public role for Christian ethics. What is required is to proclaim and enhance 'distinctively thick Christian views' as complementary to more generally shared 'thin values' (De Villiers 2003:33-34).

\section{Fifth statement}

One could ask two sets of critical questions with regard to De Villiers's work: the first relates to the theological quality of his ethics and the second to his Christian version of Weber's ethics of responsibility.

It is an interesting question whether De Villiers really develops a theological ethics, or whether he is actually a moral philosopher focusing on meta-ethical questions about

9.See De Villiers's (1978) doctoral dissertation, which deals exactly with this question, as well as his recent self-critical reflection on the narrow moral philosophical view that informed his work at that time (De Villiers 2010a:56-57, 62).

10.The significant theological and methodological issues behind this statement lie beyond the scope of this paper. The whole struggle between Barth's insistence that an apologetics which attempts to answer to the demands of modern man must in the end fail, and those such as Schleiermacher and others who see it exactly as the task of theology to be 'rational' and adhere to acceptable scientific criteria (Scholtz) comes to mind. De Villiers does refer to the 'later' Barth in his criteria (Scholtz), comes to mind. De Villiers does refer to the 'later' Barth in his (Barth's) exposition of the humanisation of society in Christengemeinde und Bürgergemeinde published in 1946 (see De Villiers 2008:381). A concise summary of the science of philosophy debates with regards to Barth and Scholtz can be
found in Van Huyssteen (1986:23-36).

11.This broadening of his view can be read in more detail in De Villiers (2005:525-526, 2008:381). the distinctiveness and intelligibility of Christian moral claims? As earlier indicated, he does place himself within the Reformed tradition, but he does not actually build a theological basis for this ethics. One of the marks of the Reformed tradition is the unity between doctrine and life; theo-logy and ethics (Smit 2010:9-11), where the former informs and guides the latter. De Villiers does not fully exploit this important mark of being Reformed.

Let us take a Trinitarian view as example: social ethics is not only based on a vision of the kingdom of God and God's rule over history, but on the very being and character of God who reveals Godself as love and justice, and as standing with the widows, the orphans and the oppressed - as the fourth article of the Belhar confession ${ }^{12}$ reminds us.

The reconciliation in Christ does not only reconcile us as totally corrupt people with God. The incarnation and humanity of Jesus Christ - fully divine and fully human is an exemplar of God's humanising work of salvation. The upsurge in 'Christian humanism' by, for example, Chicago ethicist William Schweiker (2004:31-49) and South African, John de Gruchy (2006:38-65), is a fruitful dialogue partner. The idea of a Christian humanism may enable one to build a bridge between the purported exclusive Christian and more general human views of justice and the integrity of creation claimed as reference points in De Villiers's later work.

Concerning the third Person in the Trinity, De Villiers does perhaps not make enough of the social-ethical potential in our understanding of the Spirit of God. The link between pneumatology and ethics - from social justice and equality to ecological perspectives embedded in the cosmic work of the Spirit - is a powerful one and should feature in any theologically inclined ethics.

Apart from the three persons of the Trinity taken each separately, the actual social-ethical interpretation of the Trinity (immanent and economic) has received interesting attention in the work of Miroslav Volf (see e.g. 1998:403-423) with some legitimate critique on a too easy analogy between the Trinity and humanity. Yet, it is probably unfair to expect a stronger and more explicit theological exposition from De Villiers. He may simply respond that this was not what he set out to do. His task was - he could claim - to read the signs of the time, put ethical issues on the table and provide practical guidelines in a sociologically inclined applied ethics. A response could be that it is worth exploring whether an ethic of responsibility that claims the title 'Christian' would not be open to a richer tapestry of meanings if informed by overt theological and Trinitarian reflection.

A second set of critical questions may be addressed to the Weberian interpretation which De Villiers puts forward. Weber argues for an ethics of responsibility exactly to escape what he terms as a Christian Gesinnungsethik. The question is whether De Villiers honours this intention in his retention of 12.For the text of the Belhar confession and a specific discussion of the fourth article, read Naude (2010:5-20, 201-219). 
a 'distinctive Christian version' of this type of ethics, arguing (against Weber) for the primacy of moral (and Christian) values over functional values (De Villiers 2010b:273).

On what grounds does De Villiers argue for the systemimmanence of functional values, whilst maintaining the transsystemic nature of Christian or moral values? What features do Christian values demonstrate and which are so different from functional values that the former can be assumed to transcend the social structure of the church, where (one could argue) they exactly are functional values supporting a religious institution? This is both a theological and a sociological question. Even if one accepts the over-arching system-transcendent character of Christian values, in what way are social institutions (such as politics and economics) protected against the often ideological interpretation and practice of these Christian values? Unless these questions are answered satisfactorily, it would be difficult to hold onto the specific Christian contribution toward an ethics of responsibility and toward arguing that Christians can indeed make a unique contribution to construct an economic ethics.

\section{Sixth statement}

Etienne de Villiers's significant contribution lies in his ability to interpret contexts and then ask the right ethical question at the right time. What might on the surface of history appear as not so significant topics, were in fact each and every time 'kairos-type' questions with a significance not only within the narrow confines of the DRC, but for the wider South African society.

This article focuses on the economic-ethical dimensions in De Villiers's work. Let us close the discussion by demonstrating that his contributions far exceed the narrow questions of economic justice in a post-apartheid South Africa and in a globalised world.

For example, the debate about the Immorality Act No. 23 of 1957 (Union of South Africa 1957) and the Prohibition of Mixed Marriages Act No. 55 of $1949^{13}$ (Union of South Africa 1949), which emerged around 1984, was in fact a question about racism and the over-stepping of state power into the private lives of citizens. The question about the true Christian meaning of peace ${ }^{14}$ and an ethics of peace, which emerged around 1988-1989 was, in fact, a question about the moral legitimacy of 'the war on the border' and the right of individual freedom and conscience to resist conscription into what was considered by some to be an unjust war. The question, raised in 1990, about values for an inclusive democracy ${ }^{15}$ was, in fact, a question about what kind of morality would inform the building of a new South Africa. The question about modernity, secularism and a liberal constitution after 1994 was, in fact, a question of how a public ${ }^{16}$ Christian witness

13.See the publication Op die skaal: gemengde huwelike en ontug, edited by De Villiers and Kinghorn (1984).

14. Read De Villiers (1983) about conscientious objection and De Villiers (1989) about conceptions of peace.

15.Read The option for inclusive democracy, jointly edited by Bernard Lategan, Johann Kinghorn, Lourens du Plessis and Etienne de Villiers (1990).

16.For an exposition of the challenges facing public theology in a democracy, as well as an overview of perspectives on public theology in South Africa, read De Villiers (2011). For an analysis of De Villiers as public theologian himself, read the unpublished dissertation by Ronell Bezuidenhout (2007:164-245). would still be possible after liberation and how specifically White people could use their privileges for the sake of the public good. The question, in 1996 and beyond, of how we could develop a common moral language ${ }^{17}$ was an attempt to construct some social cohesion into a situation of growing relativism, moral anomie and pluralism. Finally, the questions from 1991 onward about socio-economic justice and the role of the church in development were, in fact, questions about how we could embody Christian values in the practice of business and how the church could be a welcoming house of care for the poorest of the poor.

\section{Conclusion}

This article traced the interesting developments in De Villiers's thought and attempted to place his economic ethics within the context of his wider thinking, including his confessional commitment to the Reformed and humanistic traditions, the meta-ethical questions he asked about the uniqueness of the Christian morality and the way in which he drew on others to develop a credible version of a responsibility ethics. Looking back, one then sees De Villiers's immense ethical contribution to both ethical theory and applied ethics. For that we thank God who gave him as a gift to church and society. Looking forward, one hopes that he will enjoy good health and still find the time to ask the right questions at the right time, calling us to a Christian ethics of responsibility.

\section{Acknowledgements Competing interests}

The author declares that he has no financial or personal relationships which may have inappropriately influenced him in writing this paper.

\section{References}

Bezuidenhout, R., 2007, 'Re-imagining life: A reflection on "public theology" in the work of Linell Cady, Denise Ackermann, and Etienne de Villliers', DPhil dissertation, Department of Biblical and Religion Studies, Nelson Mandela Metropolitan University.

De Gruchy, J., 2006, 'Christian humanism: Reclaiming a tradition, affirming an identity', Reflections: Centre of Theological Inquiry 8, 38-65.

De Villiers, E., 1978, Die eiesoortigheid van die Christelike moral, Rodopi, Amsterdam.

De Villiers, E., 1983, 'Putting the recent debate on conscientious objection into perspective', Scriptura 8, 21-33.

De Villiers, E., 1989, 'Peace conceptions in South Africa in the light of the biblical concept of peace', Scriptura 28, 24-40.

De Villiers, E., 1991, "n Regverdige ekonomiese stelsel', in E. de Villiers \& D. Kitching (eds.), Derdegelui vir more. Die NG kerk voor die uitdagings van 'n nuwe tyd, pp. 18-29, Tafelberg, Cape Town.

De Villiers, E., 1995a, 'Die NG Kerk en die Heropbou- en Ontwikkelingsprogram', in D. Kitching \& F. Linde (eds.), Geroep om te dien. 'n Huldigingsbundel opgedra aan prof. P.R. van Dyk, rektor van die Hugenote Kollege 1979-1995, pp. 22-30, aan prof. P.R. van Dyk, rektor
Hugenote Kollege, Wellington.

De Villiers, E., 1995b, 'Die Nederduitse Gereformeerde Kerk en die nuwe situasie in die samelewing', Nederduits Gereformeerde Teologiese Tydksrif XXXVI(4), 558-569.

De Villiers, E., 1999a, 'Challenges to Christian ethics in the present South African society', Scriptura 69, 75-91.

De Villiers, E., 1999b, 'Die NG Kerk en die oorgang na 'n nuwe Suid-Afrika', Skrif en Kerk 20(1), 15-38.

De Villiers, E., 2001a, 'How my mind has changed', Journal of Theology for Southern Africa 111, 17-21.

De Villiers, E., 2001b, 'Teologiekroniek - Die kerk en ekonomiese globalisering', Verbum et Ecclesia 22(2), 465-477.

17.De Villiers published three articles with Dirk Smit on the topic of moral judgements See especially De Villiers and Smit (1996). 
De Villiers, E., 2001c, 'The influence of the Dutch Reformed Church (DRC) on public policy during the late 80 s and $90 \mathrm{~s}^{\prime}$, Scriptura $76,51-61$.

De Villiers, E., 2003, 'A Christian ethics of responsibility: Does it provide an adequate theoretical framework for dealing with issues of public morality?', Scriptura 82 23-38.

De Villiers, E., 2005, 'The vocation of Reformed ethicist in the present South African society', Scriptura 89, 521-535.

De Villiers, E., 2008, 'Kan die NG Kerk nog 'n konstruktiewe rol in die Suid-Afrikaanse samelewing speel?', Verbum et Ecclesia 29(2), 368-386.

De Villiers, E., 2010a, 'Defining morality in Christian ethics and the study of New Testament ethics', in R. Zimmerman \& J.G. van der Watt (eds.), Moral language in the New Testament, pp. 51-66, Mohr Siebeck, Tübingen.

De Villiers, E., 2010b, 'The recognition of human dignity in Africa: A Christian ethics of responsibility perspective', Scriptura 104, 263-278.

De Villiers, E., 2011, 'Public theology in the South African context', International Journa of Public Theology 5(1), 5-22. http://dx.doi.org/10.1163/156973211X543715

De Villiers, E. \& De Beer, S., 2009, 'Van verhaal tot beleid: Die kerk se verantwoordelikheid ten aansien van arm mense in Nederland en Suid-Afrika. ' verantwoordelikheidsetiese benadering', in F.G. Immink \& C. Vos (eds.), God in 'n kantelende wereld, pp. 109-134, Protea Boekehuis, Pretoria.

De Villiers, E. \& Kinghorn, J., 1984, Op die skaal: Gemengde huwelike en ontug, Tafelberg, Cape Town.

De Villiers, D.E. \& Smit D.J., 1996, 'Waarom verskil ons so oor wat die wil van God is? Opmerkings oor Chistelike morele oordeelingsvorming', Skrif en Kerk 17(1), $31-47$
Jonker, W., 2008, Die relevansie van die kerk, Bybel-media, Wellington.

Lategan, B., Kinghorn, J., Du Plessis, L. \& De Villiers, E., 1990, The option for inclusive democracy A theological-ethical study of appropriate social values for South Africa, Centre for Contextual Hermeneutics, Stellenbosch.

Naude, P.J., 2010, Neither calendar nor clock. Perspectives on the Belhar confession, Eerdmans, Grand Rapids.

Rawls, J., 1993, Political liberalism, Columbia University Press, New York.

Schweiker, W., 2004, 'We are not our own: On the possibility of a new Christian humanism', in M. Welker \& C.A. Jarvis (eds.), Loving God with our minds: The pastor as theologian, pp. 31-49, Eerdmans, Grand Rapids.

Smit, D.J., 2010, 'Trends and directions in Reformed theology', The Expository Times 122(7), 1-14.

Strauss, P.J., 2011, 'Kerk en samelewing in die dokumente "Kerk en Samelewing" na 25 jaar', Nederduits Gereformeerde Teologiese Tydskrif 52(3\&4), 511-520.

Union of South Africa, 1949, Prohibition of Mixed Marriages Act (Act No. 55 of 1949), Government Printers, Pretoria.

Union of South Africa, 1957, Immorality Act (Act No. 23 of 1957), Government Printers, Pretoria.

Van Huyssteen, W., 1986, Teologie as kritiese geloofsverantwoording: Teorievorming in die sistematiese teologie, Raad vir Geesteswetenskaplike Navorsing, Pretoria.

Volf, M., 1998, "The Trinity is our social program": The doctrine of the Trinity and the shape of social engagement', Modern Theology 14(3), 403-423. 